\begin{tabular}{|l|l|l|}
\hline \multicolumn{2}{|c|}{ PublisherInfo } \\
\hline \hline PublisherName & $:$ & BioMed Central \\
\hline \hline PublisherLocation & $:$ & London \\
\hline \hline PublisherImprintName & $:$ & BioMed Central \\
\hline \hline
\end{tabular}

\title{
Microbead expression arrays
}

\begin{tabular}{|l|l|l||}
\hline \multicolumn{2}{|c|}{ ArticleInfo } \\
\hline \hline ArticleID & $:$ & 3694 \\
\hline \hline ArticleDOI & $:$ & $10.1186 /$ gb-spotlight-20000606-01 \\
\hline \hline ArticleCitationID & $:$ & spotlight-20000606-01 \\
\hline \hline ArticleSequenceNumber & $:$ & 131 \\
\hline \hline ArticleCategory & $:$ & Research news \\
\hline \hline ArticleFirstPage & $:$ & 1 \\
\hline \hline ArticleLastPage & $:$ & 2 \\
\hline \hline & & RegistrationDate : 2000-06-06 \\
ArticleHistory & $:$ & OnlineDate $\quad$ 2000-06-06 \\
\hline \hline ArticleCopyright & $:$ & BioMed Central Ltd2000 \\
\hline \hline ArticleGrants & $:$ & \\
\hline \hline ArticleContext & $:$ & 130591111 \\
\hline \hline
\end{tabular}




\section{William Wells}

Email: wells@biotext.com

Strategies for expression analysis range from exhaustive sequencing (and thus counting) of cDNAs to hybridization arrays. In the June issue of Nature Biotechnology Brenner et al. describe a method that combines the digital precision of the former with the speed and throughput of the latter (Nat. Biotech. 2000, 18:630-634). Brenner et al. attach tagged cDNAs to microbeads and then sequence the overhanging ends of the cDNAs by detecting the hybridization of fluorescently labeled probes. After one overhang is identified, a binding site for a type IIs restriction endonuclease (within the probe) is used to cleave a distant cleavage site (within the cDNA sequence) to expose a new overhang. The coming and going of fluorescent probes is monitored by confocal microscopy of the microbeads, which are immobilized in a flow cell. Hundreds of thousands of mRNAs are identified in a few days, exceeding the throughput per machine of conventional sequencers by over 10-fold.

\section{References}

1. Serial analysis of gene expression.

2. Quantitative monitoring of gene expression patterns with a complementary DNA microarray.

3. Nature Biotechnology, [http://www.nature.com/nbt/] 